\title{
Biochemical Evaluation of Quality Parameters in Rice (Oryza sativa L.)
}

\author{
Rajesh Panchal*, Madhu Bala, Kalpesh Raval and Unnati Vaghela \\ Department of Genetics and Plant Breeding, NMCA, NAU, Navsari-396 450, Gujarat, India \\ *Corresponding author
}

Keywords

Line $\mathrm{x}$ Tester,

Heterosis,

Combining ability,

Biochemical

parameter

Article Info

Accepted:

04 September 2019

Available Online:

10 October 2019

\section{A B S T R A C T}

The above entitled experiment "Biochemical evaluation of quality parameters in Rice (Oryza sativa L.)" was undertaken to determine the heterosis and combining ability for different biochemical parameters from $\mathrm{F}_{1}$ seeds of rice developed by line $\mathrm{x}$ tester mating design. The experiment was conducted in kharif 2018-19 in Randomized Block Design (RBD) with 3 replications at Main Rice Research Centre, Navsari Agricultural University, Navsari, consisting of 39 genotypes representing 7 lines, 4 testers and their resulting 28 crosses. A considerable spectrum of both the type of heterosis i.e., relative heterosis and heterobeltiosis was recorded for all the biochemical parameters under investigation. Whereas combining ability analysis revealed that good general combiners and specific combiners were observed for all the biochemical parameters included in investigation.

\section{Introduction}

Rice (Oryza sativa L.) belongs to the genus Oryza, family Poaceae, was domesticated probably in north-eastern India and southern China about 8000 years ago and is the staple food for more than $50 \%$ of the world's population (Gowda et al., 2003). It accounts for over $20 \%$ of global calorie intake. Over $90 \%$ of the world's rice is produced and consumed in the Asian region with 6 countries (China, India, Indonesia, Bangladesh, Vietnam and Japan) accounted for $80 \%$ in the world's production and consumption (Abdullah et al.,
2015). The world's population is projected to reach 9.7 billion by year 2050 .

\section{Materials and Methods}

The present investigation was carried out to elicit information on magnitude of average heterosis and heterobeltiosis for rice yield and its component traits. The experiment was conducted during kharif 2018 at Main Rice Research Centre, Navsari Agricultural University, Navsari. The experimental materials for present investigation consisted of 7 lines and 4 testers, which include NVSR- 
391， NVSR-395， NVSR-396, NVSR-397, NVSR-398, NVSR-2394 and NVSR-2475 as lines, whereas NAUR-1, GNR-3, GNR-6 and GR-4 as testers. The crossing programme was carried out using 7 lines and 4 testers by hand emasculation and pollination at MRRC, NAU, Navsari during summer 2017. Total 28 crosses were obtained through line $\mathrm{x}$ tester design of mating. All the hybrid seeds and selfed parental seeds were harvested, cleaned and handled properly in seed bag for sowing in the next season i.e., kharif 2018. The experiment was laid out in a randomized complete block design with three replications. Each entry was planted in a single row consisting of ten plants in each row with a spacing of $20 \mathrm{~cm} \times 15 \mathrm{~cm}$. The standard agronomical practices were followed to raise the good experimental crop. Five competitive plants excluding border plant were randomly selected to record the observation on four biochemical parameters viz., protein (\%), amylose (\%), zinc (ppm) and iron (ppm).

\section{Results and Discussion}

\section{Heterosis}

The analysis of variance was performed to test the difference among parents and hybrids for all the biochemical parameters and is presented in the Table 1. The results revealed that the mean squares due to genotypes were highly significant for all the parameters, which indicated the considerable amount of variability among genotypes for various parameters. Mean squares due to genotypes were further partitioned into parents, hybrids and parents vs. hybrids. The difference between parents was highly significant for all the parameters. Among parents, mean squares due to lines were significant for all parameters, while in case of testers, mean squares were found to be highly significant for all parameters indicating the presence of wide genetic variability among parents for all the parameters. Mean squares due to lines vs testers were significant for all parameters except protein (\%). Mean squares due to parents $v s$. hybrids comparison were found highly significant for all parameters indicating potential amount of heterosis among hybrids. The analysis of variance further revealed that hybrids differed highly significantly for all parameters which indicated that the performance of hybrids were different from that of parents thereby supporting the presence of heterosis for all of the traits. The phenomenon of heterosis has provided the most important genetic tool in improving yield of crop plants.

In present investigation, the degree of heterosis varied from cross to cross and parameter to parameter. For a specific parameter, considerable high heterotic effects were observed in certain crosses and low in others, which revealed that nature of gene action varied with the genetic makeup of parents. The measures of heterosis over better parent (heterobeltiosis) are better rational parameters for assessing its practical utility. Therefore, in present investigation heterosis is reported over better parent. Positive heterosis was considered as desirable. The present study is an attempt to assess the possibilities of commercial exploitation of heterosis and to develop better varieties and elite lines for further breeding programme.

The results in this direction are discussed in following ways. As regards to heterosis over mid parent a good number of crosses registered significance in desired direction, for different traits like days to protein (\%) in 12 crosses, amylose (\%) in 8 crosses, zinc (ppm) in 12 crosses and iron (ppm) in 11 crosses. As regards to heterosis over better parent i.e., heterobeltiosis, a good number of crosses registered significant heterobeltiosis in desired direction, for different traits like protein $(\%)$ in 8 crosses, amylose in 3 crosses, zinc (ppm) in 
7 crosses and iron (ppm) in 5crosses. The information on number of hybrids showing significant heterosis and range of heterosis for various parameters in rice is presented in Table 2.

\section{Protein $(\%)$}

The results for protein content revealed that 12 crosses had significant and positive heterosis over mid parent, while 8 crosses had significant and positive heterosis over better parent. The crossNVSR-395 x GNR-6 had reported highest magnitude of both the types of heterosis. The emphasis should be given to these cross to develop rice varieties high protein content by pedigree method. Comparable harmony for this character was also recorded by Shinde and Patel (2014), Nayak et al., (2015), Patel and Patel (2015) and Patel et al., (2018).

\section{Amylose (\%)}

For amylose content out of 28 crosses, 8 crosses and 3 crosses exhibitedsignificant and positive heterosis over mid parent and better parent, respectively. The cross NVSR-398 x GNR-3 exhibited significantly highest positive heterosis over mid parent and better parent. Roy et al., (2009), Shinde and Patel (2014), Mistry et al., (2015), Patel and Patel (2015), Bano and Singh (2018) and Patel et al., (2018) reported the similar instances.

\section{Zinc (ppm)}

In present study, 12 crosses reported heterosis over mid parent, whereas 7 crosses reported heterosis over better parent for zinc content. Highest magnitude for zinc content for heterosis over mid parent and better parent were exhibited by the cross NVSR-395 $\mathrm{x}$ NAUR-1 and NVSR-396 $x$ NAUR-1, respectively. These results are in confirmation with Patel and Patel (2015) (Table 3).

\section{Iron (ppm)}

Total 11 hybrids manifested significant positive heterotic effect for iron and 5 hybrids exhibited significant positive heterobeltiosis. The cross combination NVSR-398 x GNR-3 and NVSR-395 x NAUR-1 manifested highest significant relative heterosis and heterobeltiosis, respectively. These results akin with Patel and Patel (2015).

Table.1 Analysis of variance (mean sum of square) of line x tester

\begin{tabular}{|c|c|c|c|c|c|}
\hline \multirow{2}{*}{$\begin{array}{l}\text { Sources } \\
\text { variation }\end{array}$} & \multirow[t]{2}{*}{ df } & \multicolumn{4}{|l|}{ Parameters } \\
\hline & & Protein $(\%)$ & Amylose (\%) & Zinc (ppm) & Iron (ppm) \\
\hline Replications & 2 & 0.05 & 0.96 & 0.18 & 1.06 \\
\hline Genotypes & 38 & $2.70 * *$ & $11.43^{* *}$ & $23.67 * *$ & $32.62 * *$ \\
\hline Parents & 10 & $1.74 * *$ & $9.00 * *$ & $29.04 * *$ & $43.49^{* *}$ \\
\hline Lines & 6 & $2.24 * *$ & $6.10^{* *}$ & $18.33^{* *}$ & $13.66^{* *}$ \\
\hline Testers & 3 & $1.25^{* *}$ & $10.35^{* *}$ & $17.67 * *$ & $66.89 * *$ \\
\hline Lines vs Testers & 1 & 0.22 & $22.36^{* *}$ & $127.37 * *$ & $152.30^{* * *}$ \\
\hline Parents vs hybrids & 1 & $4.93 * *$ & $15.04 * *$ & $36.58 * *$ & $150.11 * *$ \\
\hline Hybrids & 27 & $2.97 * *$ & $12.19^{* *}$ & $21.21^{* *}$ & $24.24 * *$ \\
\hline Error & 76 & 0.07 & 1.10 & 0.30 & 1.43 \\
\hline
\end{tabular}


Table.2 Number of hybrids showing significant heterosis and range of heterosis in rice

\begin{tabular}{|c|c|c|c|c|c|c|}
\hline \multirow[t]{3}{*}{ Parameters } & \multicolumn{4}{|c|}{$\begin{array}{c}\text { No. of hybrids showing significant } \\
\text { heterosis over }\end{array}$} & \multicolumn{2}{|c|}{ Range of heterosis (\%) over } \\
\hline & \multicolumn{2}{|c|}{ Mid Parent } & \multicolumn{2}{|c|}{ Better parent } & \multirow[t]{2}{*}{ Mid Parent } & \multirow[t]{2}{*}{ Better parent } \\
\hline & $\mathbf{P}(+)$ & $\mathbf{N}(-)$ & $\mathbf{P}(+)$ & $\mathbf{N}(-)$ & & \\
\hline Protein $(\%)$ & 12 & 05 & 08 & 08 & -20.78 to 61.39 & -26.27 to 44.91 \\
\hline Amylose (\%) & 08 & 03 & 03 & 04 & -13.30 to 18.94 & -18.93 to 18.15 \\
\hline Zinc (ppm) & 12 & 07 & 07 & 18 & -34.98 to 40.01 & -49.19 to 25.26 \\
\hline Iron (ppm) & 11 & 01 & 05 & 10 & -8.19 to 21.78 & -16.44 to 15.55 \\
\hline
\end{tabular}

Table.3 Estimation of heterosis in $\mathrm{F}_{1}$ over Mid parent (MP) and Better parent (BP)

\begin{tabular}{|c|c|c|c|c|c|c|c|c|}
\hline \multirow[t]{2}{*}{ Crosses } & \multicolumn{2}{|c|}{ Protein (\%) } & \multicolumn{2}{|c|}{ Amylose (\%) } & \multicolumn{2}{|c|}{ Zinc (ppm) } & \multicolumn{2}{|c|}{ Iron (ppm) } \\
\hline & MP & BP & MP & BP & MP & BP & MP & BP \\
\hline NVSR-391 x NAUR-1 & 0.25 & -1.23 & 1.36 & -3.54 & 0.72 & -2.98 & 1.63 & $-6.76^{*}$ \\
\hline NVSR-391 x GNR-3 & -4.49 & $-13.00 * *$ & -5.27 & -6.49 & $-27.26 * *$ & $-37.13 * *$ & 2.48 & $-10.18 * *$ \\
\hline NVSR-391 x GNR-6 & $12.61 * *$ & 4.32 & -1.48 & -5.84 & $5.85^{*}$ & $-6.12 *$ & 4.65 & 1.58 \\
\hline NVSR-391 x GR-4 & -2.96 & -4.32 & -2.75 & -4.43 & 1.87 & $-14.16^{* *}$ & 2.76 & 1.04 \\
\hline NVSR-395 x NAUR-1 & $47.16^{* *}$ & $22.03 * *$ & $-13.30 * *$ & $-18.93 * *$ & $40.01 * *$ & $23.29 * *$ & $21.04 * *$ & $15.55 * *$ \\
\hline NVSR-395 x GNR-3 & $50.85 * *$ & $37.70 * *$ & 3.53 & 0.34 & -3.58 & $-22.94 * *$ & $-8.19 * *$ & $-16.44 * *$ \\
\hline NVSR-395 x GNR-6 & $61.39 * *$ & $44.91 * *$ & -3.56 & -6.15 & $26.50 * *$ & 3.46 & 2.71 & -4.26 \\
\hline NVSR-395 x GR-4 & $19.69 * *$ & 1.62 & -0.14 & -3.63 & $-34.98 * *$ & $-49.19 * *$ & 0.79 & -1.72 \\
\hline NVSR-396 $x$ NAUR-1 & 5.28 & 3.20 & $7.10 *$ & -3.82 & $32.23 * *$ & $25.26 * *$ & $13.69 * *$ & -0.08 \\
\hline NVSR-396 x GNR-3 & $30.53 * *$ & $19.45 * *$ & $-8.20 *$ & $-14.69 * *$ & 0.63 & $-5.45^{*}$ & 2.65 & $-13.60 * *$ \\
\hline NVSR-396 x GNR-6 & $-20.78 * *$ & $-26.27 * *$ & 3.48 & 1.77 & $-12.84 * *$ & $-15.73 * *$ & $13.69 * *$ & $11.66 * *$ \\
\hline NVSR-396 x GR-4 & 2.20 & 1.28 & 0.40 & -7.08 & 1.73 & $-7.09 * *$ & $6.78 *$ & 0.22 \\
\hline NVSR-397 x NAUR-1 & -2.34 & $-8.62 * *$ & 1.99 & -6.06 & $-4.96 *$ & $-12.82 * *$ & -2.82 & $-10.07 * *$ \\
\hline NVSR-397 x GNR-3 & $14.59 * *$ & $9.73 * *$ & 0.76 & -3.86 & $-6.38 * *$ & $-9.08 * *$ & 1.62 & $-10.19 * *$ \\
\hline NVSR-397 x GNR-6 & $-13.66^{* *}$ & $-15.84 * *$ & 3.78 & 2.62 & $-14.5^{* *}$ & $-14.53 * *$ & 5.03 & 1.01 \\
\hline NVSR-397 x GR-4 & -4.45 & $-8.10 *$ & 3.07 & -2.08 & 1.22 & $-4.55^{*}$ & $14.53 * *$ & $13.67 * *$ \\
\hline NVSR-398 x NAUR-1 & $24.04 * *$ & $13.55 * *$ & 4.25 & 1.12 & $26.09 * *$ & $21.71 * *$ & 4.19 & $-8.12 * *$ \\
\hline NVSR-398 x GNR-3 & $12.77 * *$ & $10.50 * *$ & $18.94 * *$ & $18.15^{* *}$ & $22.21 * *$ & $5.83 * *$ & $21.78 * *$ & 2.83 \\
\hline NVSR-398 x GNR-6 & -6.15 & -6.35 & $7.19 *$ & 0.54 & $22.33 * *$ & $8.71 * *$ & 1.66 & 0.22 \\
\hline NVSR-398 x GR-4 & -0.61 & -6.53 & $7.95 *$ & $7.71 *$ & $7.64 * *$ & $-9.14 * *$ & $20.39 * *$ & $13.40 * *$ \\
\hline NVSR-2394 x NAUR-1 & -4.25 & -5.04 & $8.72 * *$ & 0.39 & $27.24 * *$ & $19.11 * *$ & 3.83 & $-10.69 * *$ \\
\hline NVSR-2394 x GNR-3 & $9.05 * *$ & -2.71 & $9.41 * *$ & 4.67 & 3.19 & $-13.02 * *$ & 5.42 & $-13.05 * *$ \\
\hline NVSR-2394 x GNR-6 & $-11.01 * *$ & $-19.29 * *$ & $-8.88^{*}$ & $-10.15^{*}$ & -4.27 & $-17.27 * *$ & $17.41 * *$ & $12.51 * *$ \\
\hline NVSR-2394 x GR 4 & $11.49 * *$ & $7.46^{*}$ & $13.48 * *$ & $8.09 *$ & $11.49 * *$ & $-8.30 * *$ & $13.23 * *$ & 3.82 \\
\hline NVSR-2475 x NAUR-1 & $15.33 * *$ & 1.58 & 4.68 & $-6.78 *$ & $23.43 * *$ & $14.49 * *$ & $6.23 *$ & -4.84 \\
\hline NVSR-2475 x GNR-3 & 5.03 & 2.66 & 1.00 & -6.96 & $-15.94 * *$ & $-29.71 * *$ & $8.36 * *$ & $-7.14 *$ \\
\hline NVSR-2475 x GNR-6 & $-19.35 * *$ & $-22.57 * *$ & 4.25 & 1.58 & -3.96 & $-17.69 * *$ & 1.46 & 1.09 \\
\hline NVSR-2475 x GR-4 & $-7.72 *$ & $-16.61 * *$ & $6.92 *$ & -1.91 & $5.86 * *$ & $-13.59 * *$ & 3.31 & -1.01 \\
\hline S.E. $($ d $) \pm$ & 0.19 & 0.21 & 0.74 & 0.86 & 0.38 & 0.44 & 0.85 & 0.98 \\
\hline C.D. at $5 \%$ & 0.37 & 0.43 & 1.49 & 1.72 & 0.77 & 0.89 & 1.70 & 1.96 \\
\hline C.D. at $1 \%$ & 0.49 & 0.57 & 1.98 & 2.29 & 1.03 & 1.19 & 2.26 & 2.61 \\
\hline Range & $\begin{array}{c}-20.78 \text { to } \\
61.39\end{array}$ & $\begin{array}{c}-26.27 \text { to } \\
44.91\end{array}$ & $\begin{array}{c}-13.30 \text { to } \\
18.94\end{array}$ & $\begin{array}{c}-18.93 \text { to } \\
18.15\end{array}$ & $\begin{array}{c}-34.98 \text { to } \\
40.01\end{array}$ & $\begin{array}{c}-49.19 \text { to } \\
25.26\end{array}$ & $\begin{array}{c}-8.19 \text { to } \\
21.78\end{array}$ & $\begin{array}{c}-16.44 \text { to } \\
15.55\end{array}$ \\
\hline
\end{tabular}


Table.4 Mean sum of squares due to general and specific combining ability

\begin{tabular}{|c|c|c|c|c|c|}
\hline Sources of variation & df & \multicolumn{4}{|c|}{ Parameters } \\
\hline 1. Replications & 2 & 0.06 & 2.37 & 0.11 & 2.81 \\
\hline 2. Hybrids & 27 & $2.97 * *$ & $12.19 * *$ & $21.21 * *$ & $24.24 * *$ \\
\hline 3. Line effect & 6 & $4.96^{*}$ & $22.76^{*}$ & 29.49 & 6.30 \\
\hline 4. Tester effect & 3 & $6.48^{*}$ & $27.76^{*}$ & 11.92 & $104.42 * *$ \\
\hline 5. Line $\times$ Tester & 18 & $1.73 * *$ & $6.08 * *$ & $19.99 * *$ & $16.86^{* *}$ \\
\hline 6. Error & 54 & 0.09 & 1.22 & 0.35 & 1.25 \\
\hline \multicolumn{6}{|l|}{ Estimates } \\
\hline$\sigma_{1}^{2}$ & & $0.41^{*}$ & $1.80^{*}$ & 2.43 & 0.41 \\
\hline$\sigma_{t}^{2}$ & & $0.31^{*}$ & $1.27 *$ & 0.55 & $4.90 * *$ \\
\hline$\sigma^{2}$ gca & & $0.34 * *$ & $1.46^{* *}$ & 1.24 & $3.27 * *$ \\
\hline$\sigma^{2}$ sca & & $0.55^{* *}$ & $1.66^{* *}$ & $6.57 * *$ & $5.14 * *$ \\
\hline$\sigma^{2}$ gca $/ \sigma^{2}$ sca & & 0.62 & 0.88 & 0.19 & 0.64 \\
\hline
\end{tabular}

Table.5 Estimation of General Combining Ability (GCA) effects of parents

\begin{tabular}{|c|c|c|c|c|}
\hline Parents & Protein $(\%)$ & Amylose (\%) & Zinc (ppm) & Iron(ppm) \\
\hline \multicolumn{5}{|l|}{ Lines } \\
\hline 1. NVSR 391 & 0.00 & -0.41 & $-1.73 * *$ & -0.57 \\
\hline 2. NVSR 395 & $1.19 * *$ & $-1.15 * *$ & $-1.39 * *$ & $1.05 * *$ \\
\hline 3. NVSR 396 & 0.15 & $-1.14 * *$ & $1.54 * *$ & -0.15 \\
\hline 4. NVSR 397 & $-0.52 * *$ & -0.18 & 0.13 & 0.14 \\
\hline 5. NVSR 398 & -0.10 & $2.79 * *$ & $2.45^{* * *}$ & $0.88^{*}$ \\
\hline 6. NVSR 2394 & $0.16^{*}$ & $0.68^{*}$ & 0.18 & -0.67 \\
\hline 7. NVSR 2475 & $-0.87 * *$ & -0.58 & $-1.17 * *$ & -0.68 \\
\hline $\operatorname{SE}\left(\mathbf{G}_{\mathbf{i}}\right)$ & 0.08 & 0.30 & 0.16 & 0.35 \\
\hline \multicolumn{5}{|l|}{ Testers } \\
\hline 1. NAUR 1 & $0.64 * *$ & $0.92 * *$ & $0.81 * *$ & $1.14 * *$ \\
\hline 2. GNR 3 & $0.16^{* *}$ & 0.19 & $-0.84 * *$ & $2.36 * *$ \\
\hline 3. GNR 6 & $-0.69 * *$ & $-1.67 * *$ & $-0.40 * *$ & $-2.73 * *$ \\
\hline 4. GR 4 & -0.11 & $0.55^{*}$ & $0.42 * *$ & $-0.77 * *$ \\
\hline $\operatorname{SE}\left(\mathbf{G}_{\mathbf{j}}\right)$ & 0.06 & 0.23 & 0.12 & 0.26 \\
\hline
\end{tabular}


Table.6 Estimation of Specific Combining Ability (SCA) effect of hybrids

\begin{tabular}{|c|c|c|c|c|c|}
\hline Sr. No. & Crosses & Protein $(\%)$ & Amylose (\%) & Zinc (ppm) & Iron (ppm) \\
\hline 1 & NVSR-391 x NAUR-1 & $-0.34 *$ & 0.87 & $-1.51 * *$ & -0.48 \\
\hline 2 & NVSR-391 x GNR-3 & $-0.83^{* *}$ & -0.88 & $-2.61 * *$ & 0.39 \\
\hline 3 & NVSR-391 x GNR-6 & $1.16^{* *}$ & 0.56 & $2.18^{* *}$ & 0.62 \\
\hline 4 & NVSR-391 x GR-4 & 0.02 & -0.55 & $1.95 * *$ & -0.54 \\
\hline 5 & NVSR-395 x NAUR-1 & 0.04 & $-2.30 * *$ & $2.38 * *$ & $5.25 * *$ \\
\hline 6 & NVSR-395 x GNR-3 & -0.30 & $1.47 *$ & -0.04 & $-3.52 * *$ \\
\hline 7 & NVSR-395 x GNR-6 & $1.23 * *$ & 0.44 & $3.69^{* *}$ & -0.27 \\
\hline 8 & NVSR-395 x GR-4 & $-0.97 * *$ & 0.38 & $-6.02 * *$ & $-1.47 *$ \\
\hline 9 & NVSR-396 x NAUR-1 & -0.19 & $1.54^{*}$ & $2.14 * *$ & 1.30 \\
\hline 10 & NVSR-396 x GNR-3 & $1.07 * *$ & $-2.07 * *$ & 0.60 & -1.28 \\
\hline 11 & NVSR-396 x GNR-6 & $-1.05^{* *}$ & 0.98 & $-2.95 * *$ & 1.17 \\
\hline 12 & NVSR-396 x GR-4 & 0.17 & -0.44 & 0.21 & -1.19 \\
\hline 13 & NVSR-397 x NAUR-1 & $-0.33^{*}$ & 0.01 & $-2.17 * *$ & $-2.28 * *$ \\
\hline 14 & NVSR-397 x GNR-3 & $0.44 * *$ & -0.48 & $1.28^{* *}$ & -0.33 \\
\hline 15 & NVSR-397 x GNR-6 & -0.22 & 0.69 & $-1.29 * *$ & 0.28 \\
\hline 16 & NVSR-397 x GR-4 & 0.11 & -0.21 & $2.18^{* *}$ & $2.34 * *$ \\
\hline 17 & NVSR-398 x NAUR-1 & $0.76^{* *}$ & -1.14 & $-1.72 * *$ & $-2.38 * *$ \\
\hline 18 & NVSR-398 x GNR-3 & -0.23 & $2.11 * *$ & $2.00 * *$ & $3.69 * *$ \\
\hline 19 & NVSR-398 x GNR-6 & $-0.33^{*}$ & -0.23 & $0.86^{* *}$ & $-2.83 * *$ \\
\hline 20 & NVSR-398 x GR-4 & -0.20 & -0.74 & $-1.14 * *$ & $1.53^{*}$ \\
\hline 21 & NVSR-2394 x NAUR-1 & -0.65 & 0.79 & 0.14 & $-1.68^{*}$ \\
\hline 22 & NVSR-2394 x GNR-3 & -0.01 & 0.67 & 0.42 & -0.56 \\
\hline 23 & NVSR-2394 x GNR-6 & -0.30 & $-2.80 * *$ & $-1.88^{* *}$ & $1.90 * *$ \\
\hline 24 & NVSR-2394 x GR-4 & $0.96 * *$ & $1.34 *$ & $1.32 * *$ & 0.35 \\
\hline 25 & NVSR-2475 x NAUR-1 & $0.71 * *$ & 0.22 & $0.75^{*}$ & 0.26 \\
\hline 26 & NVSR-2475 x GNR-3 & -0.14 & -0.82 & $-1.65^{* *}$ & $1.61^{*}$ \\
\hline 27 & NVSR-2475 x GNR-6 & $-0.49^{* *}$ & 0.37 & -0.61 & -0.86 \\
\hline \multirow[t]{2}{*}{28} & NVSR-2475 x GR-4 & -0.08 & 0.22 & $1.51 * *$ & -1.01 \\
\hline & SE (Sij) & 0.15 & 0.61 & 0.31 & 0.69 \\
\hline
\end{tabular}

\section{Combining ability}

The analysis of variance (of combining ability) for all the parameters was presented in Table 4. The nature and magnitude of estimates of genetic variance provide an idea about the relative role of fixable and nonfixable gene effects in the inheritance of character. This in turn helps in identifying suitable parents for hybridization as well as breeding method to be employed. The variation present in the hybrids was partitioned into portions attributable to lines, testers and line $\mathrm{x}$ tester sources. Analysis of variance for combining ability revealed that mean squares due to females were significant or non-significant for various parameters in rice.

The estimation of general combining ability (gca) variances for lines $\left(\sigma_{1}^{2}\right)$ were significant for protein (\%) and amylose (\%). In contrast, general combining ability (gca) variances for testers $\left(\sigma_{t}^{2}\right)$ were significant for protein $(\%)$, amylose (\%) and iron (ppm). On the other hand, specific combining ability (sca) variances for line $\mathrm{x}$ tester interactions were highly significant for all parameters. The magnitude of the gca variances was lower than sca variances for all the parameters which 
indicates thepredominance of non-additive gene action for allof the parameter. This was further supported by low magnitude of $\sigma^{2} \mathrm{gca} /$ $\sigma^{2}$ sca ratios.

General combining ability effects of females $\left(\mathrm{g}_{\mathrm{i}}\right)$ and of males $\left(\mathrm{g}_{\mathrm{j}}\right)$ as well as specific combining ability effects of crosses $\left(\mathrm{s}_{\mathrm{ij}}\right)$ for all the parameters were also estimated.

\section{General combining ability (GCA) and Specific combining ability (SCA) effects}

The GCA and SCAeffect of parents and their crosses for different traits were presented in Table 5 and Table 6, respectively. The general combining ability is defined as the average performance of a strain in a series of cross combinations. Dhillon (1975) opined that combining ability provides useful information on the choice of parents in terms of expected performance of the hybrids and progenies. Singh and Harisingh (1985) and Tiwari et al., (1993)had also suggested that parents having high GCA effect could produce transgressive segregants in $\mathrm{F}_{2}$ or later generations.

\section{Protein (\%)}

As regards to gca effects, 2 lines namely NVSR-395 (1.19) and NVSR-2394 (0.16) had significant positive gca effects. Among testers, NAUR-1 (0.64) and GNR-3 (0.16) had significant positive gca effects for protein.

The range of sca effect of protein in cross combination varied from -1.05 (NVSR-396 xGNR-6) to 1.23 (NVSR-395 x GNR-6). A total of 3 crosses had significant sca effect in desirable direction. The three top ranking cross combinations having desirable sca effect wereNVSR-395 x GNR-6 (1.23), NVSR-391 $x$ GNR-6 (1.13) andNVSR-396 x GNR-3 (1.07). All the crosses which had significant sca effects were classified as good specific combiners for protein content.

\section{Amylose (\%)}

With a view to gca effect of lines, 2 lines namely NVSR-398 (2.79) and NVSR-2394 (0.68) possessed significant gca effects. Besides this, testers NAUR-1 (0.92) and GR40 (0.55) had significant gca effect in desirable direction.

As regards to sca effect of crosses, it varied from -2.80(NVSR-2394 x GNR-6) to 2.11 (NVSR-398 x GNR-3). A cross combination NVSR-398 x GNR-3 (2.11) had highest significant sca effect in desirable direction followed by NVSR-396 x NAUR-1 (1.54) and NVSR-395 x GNR-3 (1.47).

\section{Zinc (ppm)}

Estimates of gca effect of lines revealed that line NVSR-398 (2.45) had highly significant and positive gca effect followed byNVSR-396 (1.54) whereas, that for testers, NAUR-1 (0.81) had highly significant and positive gca effect followed by GR-4 (0.42).

The spectrum of sca effect of cross combination varied from -6.02 (NVSR-395 x GR-4) to 3.69 (NVSR-395 x GNR-6). A total of 12 crosses had significant sca effect in desirable direction. Out of them, NVSR-395 x GNR-6 (3.69) had highest sca effect followed byNVSR-395 x NAUR-1 (2.38) and NVSR391 x GNR-6 (2.18).

\section{Iron (ppm)}

The result for iron content indicated that line NVSR-395 (1.05) had significant gca effect in desirable direction followed by NVSR-398 (0.88). Among testers, all the 4 testers reported significant gca effect but only 2 have gca effect in desirable direction.

With respect to the sca effect, lowest sca effect was possessed by cross combination 
NVSR-395 x GNR-3 (-3.52) while highest sca effect was possessed by cross combination NVSR-395 x NAUR-1 (5.25). Out of 28 cross combinations, 6 had significant sca effect in desirable direction. Among them, three top ranking cross combination were NVSR-395 x NAUR-1 (5.25), NVSR-398 x GNR-3 (3.69) andNVSR-397 x GR-4 (2.34).

\section{References}

Abdullah, A.; Kobayashi, H.; Matsumura, I. and Shoichi, I. T. O. (2015). World rice demand towards 2050: impact of decreasing demand of per capita rice consumption for China and India. Research Gate, 1-18.

Bano, D. A. and Singh, S. P (2018). Heterosis for yield and quality traits in aromatic rice (Oryza sativa. L.) genotypes. Current Journal of Applied Science and Technology, 30(6): 1-18.

Gowda, M.; Venu, R. C.; Roopalakshmi, K.; Sreerekha, M. V. and Kulkarni, R. S. (2003). Advances in rice breeding, genetics and genomics. Molecular Breeding, 11: 337-353.

Mistry, P. M.; Patel, V. J.; Chaudhari, M. H. and Desai, N. M. (2015). Heterosis and heterobeltiosis for grain yield and yield attributing traits in rice (Oryza sativa L.). BIOINFOLET, 12(1B): 212-218.

Nayak. P. G.; Sreedhar. M.; Raju. C. S. and
Vanisree, S. (2015). Heterosis studies of aromatic lines for yield and grain quality traits in rice. International journal of applied biology and pharmaceutical technology, 6(1): 232239.

Patel, A.; Rathava, K.; Gajjar, P. D.; Intwala, C. G. and Patel, P. (2018). Study of heterosis for grain yield and its components in aerobic rice (Oryza sativa L.). International Journal of Applied and Pure Bioscience, 6(6): 358-368.

Patel, R. R. and Patel, P. B. (2015). "Genetic analysis in Rice (Oryza sativa L.)". Unpublished Thesis, (Department of Genetics and Plant Breeding,) Navsari Agricultural University, Navsari.

Roy, S. K.; Senapati, B. K.; Sinhamahapatra, S. P. and Sarkar, K. K. (2009). Heterosis for yield and quality traits in rice. Oryza, 46(2): 87-93

Shinde, D. A. and Patel, P. B. (2014). Study of heterosis for improvement in aerobic rice (Oryza sativa L.). The Bioscan,9(2): 739-743.

Tiwari, D. S.; Singh, V.; Shukla, P. S. and Singh, V. (1993). Combining ability studies in mungbean (Vigna radiata (L.) Wilczek). Indian Journal of Genetics and Plant Breeding, 53(4):395-398.

\section{How to cite this article:}

Rajesh Panchal, Madhu Bala, Kalpesh Raval and Unnati Vaghela. 2019. Biochemical Evaluation of Quality Parameters in Rice (Oryza sativa L.). Int.J.Curr.Microbiol.App.Sci. 8(10): 237-244. doi: https://doi.org/10.20546/ijcmas.2019.810.024 